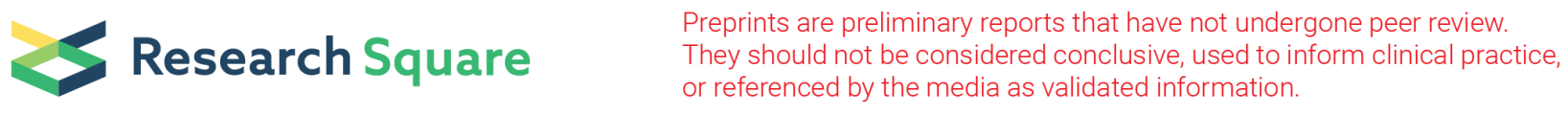

\title{
The Financial Burden of Catastrophic Health Expenditure on Households with Chronic Diseases: Financial Ratio Analysis
}

\author{
Hyunwoo Jung \\ Yonsei University \\ Young Dae Kwon \\ The Catholic University of Korea \\ Jin-Won Noh ( $\nabla$ jinwon.noh@gmail.com ) \\ Yonsei University
}

\section{Research Article}

Keywords: Catastrophic health expenditure, Chronic disease, Financial Strain

Posted Date: June 22nd, 2021

DOI: https://doi.org/10.21203/rs.3.rs-569897/v1

License: (c) (i) This work is licensed under a Creative Commons Attribution 4.0 International License. Read Full License 


\section{Abstract}

Background: The financial status of households is vulnerable to chronic disease related to high medical expenses and income loss; The financial strain could be assessed by the five indicators. household surplus indicator, liquid asset/debt ratio, solvency indicator, and liquidity indicator.

Purpose: We investigated the association between catastrophic health expenditure (CHE) and financial ratio indicators in households with chronic disease in South Korea.

Methodology: To determine the financial strain, thresholds were applied to the financial ratios. We conducted multiple logistic regression to figure out whether $\mathrm{CHE}$ is associated with financial strain. Furthermore, we analyzed the effect of $\mathrm{CHE}$ on absolute finance size, which is basic financial indicators, by multiple linear regression.

Results: When CHE occurred, all of the financial ratio indicators deteriorated. However, it was not due to decreases in the absolute size of wealth, income, but rather the relative balance between finances. Especially, the loss of the liquid assets was the major factor of deterioration. Also, all types of labor-related income deteriorated. Only the private transfer income increased.

Conclusion: This study revealed that CHE in households with chronic disease negatively impacts the household's finances. It turned out that the financial coping strategies are only resource-consuming.

\section{Introduction}

South Korea (hereafter, Korea) is now classified as a high-income country and has achieved universal health coverage by implementing a national health insurance system. However, Korea is reported as high incidence rates of catastrophic health expenditure (CHE) [1]. CHE is defined as an out-of-pocket (OOP) payment that is larger than a certain threshold of the household's ability to pay [2]. Many researchers have criticized that Korean health insurance does not play a role in relieving the OOP payment sufficiently because its benefit level is too low [3].

Chronic disease could affect household finances. First, direct medical costs, including OOP and other costs (transportation, special dietary regimes, etc.) could increase [4] (Kankeu et al., 2013, p. 2). Second, indirect costs could be incurred through a reduction in "working time" and "labor income" [4]. Although the economic impacts of chronic diseases include not only direct costs but also indirect costs.

To address these direct and indirect costs, households implement "financial coping strategies." The strategies include the use of savings; borrowing from relatives or acquaintances; liability/loan borrowing; and disposal of assets, such as housing, land, and vehicles [5]. Previous studies have argued that such financial strategies serve as buffers against economic crises $[5,6]$.

However, we do not agree that taking out liability/loans and disposing of assets can prevent economic ruin and poverty. First, regarding liability or borrowing, if they are used without considering one's ability to repay after a deterioration in health, it will lead to inextinguishable liability in the future [7]. If households fail to fulfill their obligations, they would be classified as delinquent borrowers. Those labeled delinquent borrowers could be limited in social and economic activities and be exposed to various actions -even crime- that encourage liability fulfillment [8]. Second, generally, assets are regarded as a means of bearing the cost of children's education, marriage funding, and maintaining life after retirement. They are also used as a means of investment for asset growth. Therefore, if assets are disposed of as a result of being ill, an individual will not only be unable to achieve the objectives as mentioned above but will also become an economic burden. Furthermore, disposing of assets makes it more challenging to use liability/loans because the availability of liability/loans varies depending on the size of the asset.

Many prior studies analyzing the impact of CHE on household finances were limited primarily to examining the effect on poverty measured by income. In the case of low- and middle-income countries, income could be a proxy representing the whole household economy. However, in high-income countries, the sizes of assets and the liability markets are also large that only examining the effect on income is insufficient. In fact, finances in households are very complicated. Even if assets are substantial, an individual might go bankrupt when there is not enough cash to pay off the immediate repayment. To understand these complex effects, personal finance scholars often suggest using financial ratio analysis [9]. Financial ratios are reliable indicators of financial strain 
because they allow us to identify the strengths and weaknesses of households through relative assessment, and to evaluate whether households are doing well in achieving financial goals over time $[10,11]$.

Therefore, the purpose of this study is to demonstrate whether CHE would ultimately increase financial strain in households with chronic disease, and financial coping strategies would prove only to consume more resources. To achieve this goal, we first compare the incidence rate of $\mathrm{CHE}$ in households with and without chronic diseases. Second, we analyze the effect of $\mathrm{CHE}$ on financial ratio indicators (applied threshold approach) that are measured by the ratio of two variables. Third, we analyze the basic financial indicators (financial assets, liability, income, and living expenses) that compose the financial ratio indicators because we are otherwise unable to determine which of the variables influences the financial ratio.

\section{Methods}

\section{Data}

This study utilized data from the Korea Welfare Panel Study (KoWePS), which is the covers all the cities and provinces in Korea. The KoWePS evaluated samples using a two-stage stratified cluster sampling design and collected data from household financial records and receipts of OOP to avoid recall bias. The KoWePS provides various data, such as demographic and socio-economic characteristics of individuals, OOP, and assets, liabilities, and income.

We mainly used the data from 2014, but we added data from 2015 and 2016 as needed. Specifically, since there may have been a reverse causality between the independent and dependent variables, we first set the independent variable as the data from 2014 and the dependent variable as the data from 2015. Second, the KoWePS collects data of the relevant year; however, when it comes to income and living expenses variables, it investigates data of the previous year. This is because KoWePS's survey period is so long that the response time of each subject varies. Some may be investigated in May and others in September. Also, if the survey is conducted in May, the income and living expenses cannot be represented for one year. However, other variables, such as assets or liability, gender, education level, etc., do not need consideration of response time, so that investigates data of relevant year. Therefore, we conducted a time-matching. For example, as mentioned above, we set the independent variable (CHE) as the data from 2014 and the dependent variable (i.e., surplus indicator) as the data from 2015. when calculating CHE, we used the OOP variable of 2014, and the income variable was from 2015. At the same time, when calculating the surplus indicator, we used the living expenses and income variable of 2016.

By the way, the subjects of this study are households with chronic diseases. KoWePS collects data on whether or not they have such diseases or take medicine for more than six months. If someone answered that they had a chronic disease, we set the household with that person to be a chronic disease household. Accordingly, in total, 6,270 households participated in the survey for three years, and 4,802 households had chronic diseases.

We used publicly available and reliable secondary data from KoWePS, which was provided through the de-identified samples. The investigator of KoWePS visited the participants' households, met the respondent, and received informed consent. Approval of IRB exemption for this study was granted by the Korea University Institutional Review Board (approval number: KUIRB-2019-0214-01), given the study's retrospective nature.

\section{Measures of CHE}

We calculated the independent variable CHE according to the method of Wagstaff and van Doorslaer (2003) [12]. We divided OOP by household payment ability (disposable income - food expenses) and transformed it into a binary variable. When its value was greater than the threshold (i.e., 10\%, 20\%,30\%,40\%), CHE was Yes (1), otherwise No (0). In multiple logistic and linear analysis, we used the representative threshold, $10 \%$, because it is the approximate level at which households would sell their assets to pay for OOP, pay off liability, and reduce the cost of living other than health expenditure [13]. The threshold level is a commonly used value in the empirical work conducted to date [1].

OOP of the KoWePS included costs for hospitalization, outpatient care, dental care, surgery (including implants and cosmetic surgery), medicine, nursing care, postpartum care, health checkups, and healthcare supplies (eyeglasses, contact lenses, etc.). 
There are two types of financial strain indicators of households, basic financial indicators and financial ratios [14, 15]. Firstly, the basic financial indicators comprise an absolute size of each finance components: disposable income, earned income, total living expenses with and without OOP, savings, total assets, liquid assets, non-liquid assets, and the total liability of households $[15,16]$. When it comes to income, we classified it as labor-related income (earned income and business income) and non-labor related income (property income, private transfer income, public transfer income, and other income) in order to determine whether CHE in households with chronic disease conferred a detrimental effect on individuals' work activities.

The basic financial indicators facilitate objective comparison and evaluation, though, confers limitations in assessing complex aspects of household financial conditions. It is the financial ratio indicators that allow us to better understand these complexities [9]. Financial ratio indicators are measured as the ratio of two financial elements, which a threshold can be set to determine whether there is a financial strain. As financial advisors recommend using several ratios [9], we included four indicators as follows.

\section{Surplus indicator}

The surplus indicator is a primary indicator for evaluating the adequacy of household cash flow that can help determine whether the consumption propensity is fine and whether there is a possibility of deficit in a household [17]. In this study, we measured the surplus indicator as the annual "total living expenses/disposable income" and applied a threshold of 70\% according to Yang et al. (2013) [15]. If the value exceeds 70\%, it is categorized as "dangerous."

\section{LADR}

The LADR is the concept of ability to liquidate household's total liabilities by their liquid assets. Liquid assets include deposit and installment savings of banks, stocks bonds. Total assets include liquid assets and non-current assets, such as real estate (house, non-residential building, land), agricultural machinery, livestock products (cow, pig, chicken, etc.), and current car quotations. We defined the bad condition of LADR as liquid assets that is lower than $20 \%$ of their liabilities as suggested by Griffith (1985) [18].

\section{Solvency indicator}

The solvency indicator is an indicator of a household's overall financial condition, which determines whether or not they have total assets to sustain their debts $[11,17]$. This indicator is represented by "total assets/total liabilities." Total liabilities include loans from financial institutions, general debenture, card debt, credit, and deposit on lease. We defined it as dangerous if the ratio is over $40 \%[11,15,17]$.

\section{Liquidity indicator}

The liquidity indicator assesses whether liquid assets could sustain the previous standard of living when income is temporarily suspended [15]. It can show whether cash flow and assets are well-balanced. It calculated by 'liquid assets/disposable income' and classified as bad condition if the ratio is lower than 400\% according to DeVaney (1993) and Yang et al. (2013) [11, 14].

\section{Control variables}

We chose control variables based on previous studies [19]; characteristics of household (number of household members, type of medical insurance, presence of disabled individuals, children younger than 20 years, elderly individuals aged 65 years or older) and characteristics of the householders (gender, age group, educational level, marital status, employment status). Since the independent and dependent variables in this study were household units, we did not include health-related variables, such as the type of disease and self-reported health, due to these being individual units.

\section{Statistical Analysis}

We performed three analyses. First, we compared the CHE incidence rates in households with and without chronic diseases using the Chi-square test. At this time, we represented various thresholds-10\%,20\%,30\%, and $40 \%$-to examine the sensitivity of CHE incidence.

Second, we conducted multiple logistic regression analyses to identify the relationship between the CHE and financial ratio indicators in households with chronic diseases. We transformed every dependent variable (financial ratio) to a binary variable, as good (0) or bad (1), according to each threshold suggested in the previous studies. 
However, since the financial ratio was calculated as a ratio, it was necessary to provide further shape to the model [20]. It is difficult to determine whether the increase in the proportion of the surplus indicator is due to decreased income or increased living costs [9]. Therefore, Third, we used multiple linear regression analyses to analyze the effect of CHE on basic financial indicators. All the basic financial indicators often had a non-Gaussian distribution, and since the distribution of the error term is unlikely to be a normal distribution, we applied logarithmic transformation $[9,20]$.

To test the existence of multicollinearity among the independent variables, we used the variance inflation factor (VIF). Since all the values of VIF were less than 10, the multicollinearity can be ignored. And to resolve the heteroskedasticity, we computed robust standard errors (Detailed explanations are available at https://www.stata.com/search/). This method can be simply conducted by the statistical software program, Stata version 14.0 (StataCorp, College Station, Texas, US), which we used to analyze.

\section{Results}

\section{General characteristics}

The characteristics of the samples are presented in Table 1. It is notable that most households were unemployed, $46.1 \%$, and most of the households featured an elderly resident, $67.4 \%$. These results would have stemmed from the characteristics related to chronic diseases in the KoWePS, as in the total sample of 6,270 , the unemployment rate was already $36.1 \%$, and $55.1 \%$ of households had an elderly resident. Additionally, in the results for the type of national health insurance, employees totaled $63 \%$, which contrasts with the unemployed rate of the household head. This can be interpreted as many household heads being retired and other household members working instead (Table 1). 
Table 1

Sample characteristics

\begin{tabular}{|c|c|c|c|c|c|}
\hline Variables & & & $\begin{array}{l}\text { Number of households with } \\
\text { chronic diseases }\end{array}$ & $\%$ & $\begin{array}{l}\text { Total number } \\
\text { of households }\end{array}$ \\
\hline \multirow{14}{*}{$\begin{array}{l}\text { Characteristics of } \\
\text { household head }\end{array}$} & \multirow[t]{2}{*}{ Gender } & Male & 3,208 & 66.8 & 4,381 \\
\hline & & Female & 1,594 & 33.2 & 1,889 \\
\hline & \multirow[t]{3}{*}{ Age group } & $20-39$ & 1,283 & 26.7 & 1,765 \\
\hline & & $40 \sim 64$ & 1,755 & 36.6 & 2,656 \\
\hline & & 65 or older & 1,764 & 36.7 & 1,849 \\
\hline & \multirow[t]{3}{*}{ Educational level } & $\begin{array}{l}\text { Less than } \\
\text { elementary school }\end{array}$ & 802 & 16.7 & 1,469 \\
\hline & & $\begin{array}{l}\text { Middle-high } \\
\text { school }\end{array}$ & 1,984 & 41.3 & 2,615 \\
\hline & & $\begin{array}{l}\text { Greater than } \\
\text { college }\end{array}$ & 2,016 & 42.0 & 2,186 \\
\hline & \multirow[t]{2}{*}{ Marital status } & Married & 2,794 & 58.2 & 3,800 \\
\hline & & Single & 2,008 & 41.8 & 2,470 \\
\hline & \multirow[t]{4}{*}{ Employment status } & Employee & 1,329 & 27.7 & 2,287 \\
\hline & & Employer/owner & 1,124 & 23.4 & 1,413 \\
\hline & & Other & 133 & 2.8 & 149 \\
\hline & & Unemployed & 2,216 & 46.1 & 2,421 \\
\hline \multirow{15}{*}{$\begin{array}{l}\text { Characteristics of } \\
\text { household }\end{array}$} & \multirow{4}{*}{$\begin{array}{l}\text { Number of household } \\
\text { members }\end{array}$} & 1 & 1,438 & 29.9 & 1,758 \\
\hline & & 2 & 1,795 & 37.4 & 2,051 \\
\hline & & 3 & 683 & 14.2 & 1,029 \\
\hline & & 4 or more & 886 & 18.5 & 1,432 \\
\hline & \multirow{3}{*}{$\begin{array}{l}\text { Type of National } \\
\text { health insurance }\end{array}$} & Employee & 3,028 & 63.0 & 4,026 \\
\hline & & Self-employed & 1,268 & 26.4 & 1,687 \\
\hline & & $\begin{array}{l}\text { Medical aid } \\
\text { beneficiaries }\end{array}$ & 506 & 10.6 & 557 \\
\hline & \multirow{2}{*}{$\begin{array}{l}\text { Private health } \\
\text { insurance }\end{array}$} & Insured & 2,327 & 48.5 & 3,549 \\
\hline & & Uninsured & 2,475 & 51.5 & 2,721 \\
\hline & \multirow{2}{*}{$\begin{array}{l}\text { Presence of disabled } \\
\text { person }\end{array}$} & No & 4,377 & 91.2 & 5,819 \\
\hline & & Yes & 425 & 8.8 & 451 \\
\hline & \multirow[t]{2}{*}{ Presence of children } & No & 3,935 & 82.0 & 4,690 \\
\hline & & Yes & 867 & 18.0 & 1,580 \\
\hline & \multirow[t]{2}{*}{ Presence of elderly } & No & 1,564 & 32.6 & 2,812 \\
\hline & & Yes & 3,238 & 67.4 & 3,458 \\
\hline $\begin{array}{l}\text { Note: Presence of } \\
\text { status, widows/wi } \\
\text { seniors/disabled/r } \\
\text { workers }\end{array}$ & $\begin{array}{l}\text { n indicates those under } \\
\text { s are included as single } \\
\text { who participated in the }\end{array}$ & $\begin{array}{l}0 \text { years old; presenc } \\
\text { ue to the small num } \\
\text { overnment project fo }\end{array}$ & $\begin{array}{l}\text { of elderly means those } 65 \text { yea } \\
\text { ar of cases; in employment sta } \\
\text { employment promotion, as we }\end{array}$ & $\begin{array}{l}\text { or olde } \\
\text { s, other } \\
\text { as unpa }\end{array}$ & $\begin{array}{l}\text { in marital } \\
\text { ncludes those } \\
\text { d family }\end{array}$ \\
\hline
\end{tabular}




\section{Incidence Rates of CHE}

The results of the incidence rates of $\mathrm{CHE}$ are presented in Table 2. Rates were higher in households with chronic disease. For a typical threshold of $10 \%$, the CHE incidence was only $6.5 \%$ in households without chronic disease, while it was 4.4 times higher in households with chronic disease (28.9\%). The CHE incidence rates in households with chronic disease were also high at all thresholds. In addition, thresholds greater than $20 \%$ were not suitable for various analyses because of the small sample size (Table 2).

Table 2

Different incidence rates of CHE between households with and without chronic disease

\begin{tabular}{|llllllll|}
\hline Variables & & \multicolumn{2}{l}{ Households without chronic disease } & \multicolumn{2}{l}{ Households with chronic disease } & Total & P-value \\
\cline { 3 - 6 } & & Frequency & $\%$ & Frequency & $\%$ & & \\
\hline CHE (10\%) & No & 1,372 & 93.5 & 3,414 & 71.1 & 4,786 & $<0.001$ \\
& Yes & 96 & 6.5 & 1,388 & 28.9 & 1,484 & \\
\hline CHE (20\%) & No & 1,437 & 97.9 & 4,125 & 85.9 & 5,562 & $<0.001$ \\
& Yes & 31 & 2.1 & 677 & 14.1 & 708 & \\
\hline CHE (30\%) & No & 1,459 & 99.4 & 4,451 & 92.7 & 5,910 & $<0.001$ \\
\hline & Yes & 9 & 0.6 & 351 & 7.3 & 360 & \\
\hline CHE (40\%) & No & 1,464 & 99.7 & 4,602 & 95.8 & 6,066 & $<0.001$ \\
\hline & Yes & 4 & 0.3 & 200 & 4.1 & 204 & \\
\hline Note: CHE, catastrophic health expenditure & & & & & \\
\hline
\end{tabular}

\section{vEffect of CHE on Financial Strain in Households with Chronic Disease}

Table 3 shows the effects of $\mathrm{CHE}$ on financial strain analyzed using multiple logistic and linear regression analyses. When $\mathrm{CHE}$ (threshold 10\%) occurred, all financial ratio indicators (surplus, liquidity, solvency indicator, and LADR) deteriorated significantly. Besides, it turned out that there were differences among the basic financial indicators. 
Table 3

Effect of catastrophic health expenditure on financial strain indicators in households with chronic disease

\begin{tabular}{|c|c|c|c|c|c|c|}
\hline \multirow{2}{*}{$\begin{array}{l}\text { Independent variable } \\
\text { Dependent variables }\end{array}$} & \multicolumn{6}{|c|}{ Catastrophic health expenditure (OOP/Disposable income $>0.1)$} \\
\hline & OR (SE) & Coefficient (RSE) & Constant (RSE) & $\mathbf{N}$ & $\begin{array}{l}\text { Pseudo } \mathrm{R}^{2} \\
\left(\text { Adj } \mathrm{R}^{2} \text { ) }\right.\end{array}$ & LR chi ${ }^{2}$ \\
\hline \multirow{2}{*}{$\begin{array}{l}\text { Surplus indicator } \\
(\text { TLE / Income > 0.7) }\end{array}$} & $3.248^{\star \star}$ & & $3.468^{\star \star}$ & 4,802 & 0.118 & 344.8 \\
\hline & $(0.557)$ & & $(0.971)$ & & & \\
\hline \multirow[t]{2}{*}{ Total living expenses } & & $0.058^{\star \star}$ & $7.869^{\star *}$ & 4,802 & $(0.717)$ & \\
\hline & & $(0.014)$ & $(0.035)$ & & & \\
\hline \multirow[t]{2}{*}{ Disposable income } & & $-0.164^{\star \star}$ & $7.951^{* \star}$ & 4,783 & $(0.658)$ & \\
\hline & & $(0.017)$ & $(0.04)$ & & & \\
\hline \multirow[t]{2}{*}{ LADR } & $1.301^{*}$ & & $0.069^{* \star}$ & 4,802 & 0.055 & 222.4 \\
\hline & $(0.133)$ & & $(0.015)$ & & & \\
\hline \multicolumn{7}{|l|}{ (Liquid asset / total liability < 0.2) } \\
\hline \multirow[t]{2}{*}{ Liquid assets } & & $-0.383^{\star \star}$ & $8.438^{* *}$ & 4,802 & $(0.274)$ & \\
\hline & & $(0.069)$ & $(0.164)$ & & & \\
\hline \multirow[t]{2}{*}{ Total liability } & & 0.007 & $3.767^{* *}$ & 4,802 & $(0.182)$ & \\
\hline & & $(0.123)$ & $(0.294)$ & & & \\
\hline \multirow{2}{*}{$\begin{array}{l}\text { Solvency Indicator } \\
\text { (Total asset / total liability > 0.4) }\end{array}$} & $1.448^{\star}$ & & $0.089^{\star *}$ & 4,802 & 0.055 & 222.4 \\
\hline & $(0.167)$ & & $(0.021)$ & & & \\
\hline \multirow[t]{2}{*}{ Total asset } & & $-0.146^{*}$ & $10.04^{\star *}$ & 4,802 & $(0.373)$ & \\
\hline & & $(0.056)$ & $(0.135)$ & & & \\
\hline \multirow[t]{2}{*}{ Total liability } & & 0.007 & $3.767^{\star *}$ & 4,802 & $(0.182)$ & \\
\hline & & $(0.123)$ & $(0.294)$ & & & \\
\hline \multirow{2}{*}{$\begin{array}{l}\text { Liquidity Indicator } \\
\text { (Liquid asset / income < 4) }\end{array}$} & $1.375^{*}$ & & $0.012^{\star *}$ & 4,802 & 0.067 & 129.04 \\
\hline & $(0.217)$ & & $(0.004)$ & & & \\
\hline \multirow[t]{2}{*}{ Liquid assets } & & $-0.383^{\star \star}$ & $8.438^{\star \star}$ & 4,802 & $(0.274)$ & \\
\hline & & $(0.069)$ & $(0.164)$ & & & \\
\hline \multirow[t]{2}{*}{ Disposable income } & & $-0.164^{\star \star}$ & $7.951^{* *}$ & 4,783 & $(0.658)$ & \\
\hline & & $(0.017)$ & $(0.04)$ & & & \\
\hline \multicolumn{7}{|l|}{ Supplementary } \\
\hline \multirow[t]{2}{*}{ Non-liquid assets } & & -0.036 & $9.736^{* *}$ & 4,295 & $(0.388)$ & \\
\hline & & $(0.049)$ & $(0.115)$ & & & \\
\hline
\end{tabular}




\begin{tabular}{|lccc|}
\hline Independent variable & \multicolumn{4}{c|}{ Catastrophic health expenditure (OOP/Disposable income $>0.1)$} \\
\hline Total living expenses without OOP & $-0.096^{* *}$ & $12.78^{* \star}$ & 4,802 \\
& $(0.014)$ & $(0.743)$ \\
\hline${ }^{* \star} \mathrm{p}<0.001,{ }^{*} \mathrm{p}<0.05$ & & & \\
\hline
\end{tabular}

First, the effect of CHE on the surplus indicator had an odds ratio (OR) of $3.248(P<0.000)$, which means that the indicator deteriorated. Also, as a result of further analysis to identify the cause of the deterioration in the indicators, CHE significantly decreased the logarithm of disposable income (coefficient $=-0.164$; it means $15.1 \%$ of income decreased when converted from logarithm) and increased the total living costs (coefficient $=0.058$; it means $6.0 \%$ increased). In this case, the ratio value increased because of the decreasing denominator and increasing numerator. Moreover, we analyzed the logarithm of the cost of living excluding OOP as a dependent variable. As a result, it decreased significantly (coefficient $=-0.096$; it means $9.2 \%$ reduced) when CHE occurred (below the supplementary cell).

Second, CHE deteriorates the LADR $(O R=1.301 ; P<0.05)$, which suggests that CHE weakens a household's capacity to hold liability. CHE did not affect total liability, but significantly reduced liquid assets (coefficient $=-0.383$; it means $31.8 \%$ decreased).

Third, CHE worsened the solvency index $(\mathrm{OR}=1.448 ; \mathrm{P}<0.01)$, which may have aggravated household finances in the long term and at the macro level. This indicator is composed of total liabilities and total assets. CHE did not affect total liabilities but lowered the logarithm of the total assets (coefficient $=-0.146$; it means $13.6 \%$ decreased) significantly. We further classified the types of assets into liquid assets and non-liquid assets to identify how asset reduction occurs. As a result, CHE had no significant impact on nonliquid assets. Instead, CHE is associated with reduced liquid assets.

Forth, CHE exacerbates the liquidity indicator as much as an OR of 1.375. This indicator is the ratio of disposable income to liquid assets. Since CHE confers a negative effect on both sides, it is difficult to determine which one has an impact. However, it seems that the decrease in liquid assets is more considerable than income (disposable income coefficient $=-0.164 ; 15 \%$ decreased, liquid asset coefficient $=-0.383 ; 31.8 \%$ reduced $)($ Table 3$)$.

Table 4 shows that even in households with chronic diseases, CHE still has more effect on decreasing labor-related income, which is "earned income (coefficient $=-0.385$; it means $32 \%$ decreased)" and "business income (coefficient $=-0.418$; it means $34.2 \%$ decreased)." On the other hand, of all income types, the only increase occurred in private transfer income (coefficient $=0.41$; it means $50.7 \%$ increased). On the contrary, public transfer income, which is paid by the social security system, has decreased inversely (coefficient $=-0.143$; it means $13.4 \%$ decreased) (Table 4$)$. 
Table 4

Effect of catastrophic health expenditure on each type of income

\begin{tabular}{|c|c|c|c|c|c|c|c|c|c|c|c|c|}
\hline & \multicolumn{12}{|c|}{ Dependent variables (Log) } \\
\hline & \multicolumn{4}{|c|}{ Labor-related income } & \multicolumn{8}{|c|}{ Non-labor-related income } \\
\hline & \multicolumn{2}{|c|}{ Earned income } & \multicolumn{2}{|l|}{$\begin{array}{l}\text { Business } \\
\text { income }\end{array}$} & \multicolumn{2}{|l|}{$\begin{array}{l}\text { Property } \\
\text { income }\end{array}$} & \multicolumn{2}{|c|}{$\begin{array}{l}\text { Private transfer } \\
\text { income }\end{array}$} & \multicolumn{2}{|c|}{$\begin{array}{l}\text { Public transfer } \\
\text { income }\end{array}$} & \multicolumn{2}{|c|}{ Other income } \\
\hline & Coef. & RSE & Coef. & RSE & Coef. & RSE & Coef. & RSE & Coef. & RSE & Coef. & RSE \\
\hline CHE & $-0.385^{\star *}$ & 0.044 & $-0.418^{\star \star}$ & 0.075 & -0.106 & 0.087 & $0.410^{\star *}$ & 0.048 & $-0.143^{\star *}$ & 0.030 & 0.309 & 0.064 \\
\hline Constant & $7.450 * \star$ & 0.081 & $6.057^{\star \star}$ & 0.216 & $5.172^{\star \star}$ & 0.244 & $4.791^{\star \star}$ & 0.116 & $5.749^{* \star}$ & 0.078 & $2.685^{\star \star}$ & 0.152 \\
\hline $\mathbf{N}$ & & 2,467 & & 1,627 & & 1,797 & & 4,781 & & 4,112 & & 4,709 \\
\hline Prob $>F$ & & 0.000 & & 0.000 & & 0.000 & & 0.000 & & 0.000 & & 0.000 \\
\hline $\begin{array}{l}\text { Adj R- } \\
\text { squared }\end{array}$ & & 0.607 & & 0.553 & & 0.149 & & 0.217 & & 0.179 & & 0.131 \\
\hline$* * p<0.00$ & $p<0.05$ & & & & & & & & & & & \\
\hline
\end{tabular}

\section{Discussion}

The purpose of this study was to determine whether households with chronic disease are vulnerable to $\mathrm{CHE}$ and to examine the effects of $\mathrm{CHE}$ on financial. Consequently, the incidence rate of $\mathrm{CHE}$ was higher in households with chronic disease than those without. This is because households with chronic diseases incur large OOP, and income decreases because of health deterioration. That is, the numerator increases, and the denominator decreases, potentially leading to an increase in the incidence rate of $\mathrm{CHE}$. In Korea, specifically, since the national health insurance coverage is not enough, $\mathrm{CHE}$ is highly likely to occur in households with chronic diseases [3].

Furthermore, when CHE occurs in households with chronic disease, almost all financial strain indicators deteriorated in the following year. This study involved two main analyses. First, the logistic regression was conducted to evaluate financial ratio indicators applied threshold model. Second, we analyzed the linear regression to determine which components of the ratio indicators affected.

We analyzed four financial ratio indicators: the surplus, LADR, solvency, and liquidity. To summary the results, first, the surplus indicator deteriorated. It could interrupt the cash flow. In additional analysis, it turned out that the income loss and increase in living costs affected the surplus indicator. If households with chronic diseases have $\mathrm{CHE}$, the patient could not work, and even other household members may give up the work to take care of the patient so that it could reduce income. Furthermore, it seems that medical expenses increased the total living costs. However, on the contrary, total living expenses without OOP decreased. It can be interpreted that households reduce other consumption to pay for OOP.

Secondly, LADR was deteriorated, which means that CHE weakens a household's capacity to hold liability. The LADR is an assessment of the amount of liability that can be repaid through liquid assets which can be mobilized immediately in the event of an unavoidable situation, in which a household must repay all its liability at one time $[15,18,21]$. The LADR is the ratio of total liabilities to liquid assets. As a result of the further analysis, CHE did not affect total liability, but significantly reduced liquid assets. It can be interpreted households pay for the medical costs by withdrawing liquid assets, not borrowing money from the bank. The decline in liquid assets can hinder cash flow, making expenses more difficult and increasing the burden of paying off the liabilities.

The solvency indicator has an enormous financial scale compared to other indicators, but the results showed that CHE affects it. This indicator reflects the full capacity to hold household liability, so that it should care with alert. From the further analysis, CHE had no significant impact on non-liquid assets. Instead, $\mathrm{CHE}$ is associated with reduced liquid assets. It can be interpreted that $\mathrm{CHE}$ occurs suddenly, and individuals rely on financial assets available for immediate use. Using liquid assets can be viewed as a financial coping strategy, but is not, as this will eventually lead to a decline in household finances. 
Finally, as a result of liquidity indicator, it was also deteriorated, which means households are losing ability to cope with unexpected economic problems. The increase in the liquidity indicator indicates that the money to maintain the present economic condition will disappear. In this case, households would become very unstable, both psychologically and economically.

In the results of further analysis to identify what is cause, it turned out that CHE confers a negative effect on both sides, however, the decrease in liquid assets was higher.

From the results of the four financial ratio analyses, we can figure out several facts as follows: first, the likelihood of household financial strain is high if CHE occurs in households with chronic diseases. And it is not due to a decrease in absolute wealth, income, or an increase in debt, but rather because the relative balance between financial elements is broken. Second, the main factor in the deterioration of the financial ratio index was a decrease in liquid assets. This can be interpreted as people using liquid assets rather than using debt or non-liquid assets when CHE occurs. Since three of the four indicators (LADR, solvency, and liquidity indicators) contain liquid assets, this affects all indicators in a chain. Liquid assets and income are different. Income is "newly incoming money," and liquid assets are "accumulated money" through income. For example, if an employee uses an outpatient service or even pays for expensive medicine, it will not reduce the incoming money (i.e., the salary) but reduce the accumulated money. If OOP were to affect income, then it might be the case that a patient's illness (OOP implied) is so severe that they may not be able to maintain work activities and would lose their wage. Previous studies that analyzed only the impact of CHE on income-based poverty did not point out any differences between incoming money and accumulated money.

Third, CHE increased the total cost of living and decreased income, which leads to the deterioration of the surplus indicator. Traditionally, the surplus indicator has been used for short-term evaluation [14, 15]; however, the deterioration of the indicator can develop into a long-term problem when it comes to chronic diseases because it implies loss of workability. To determine whether income reduction occurs through labor, we analyzed the effects of CHE on labor-related income and non-related income.

As a result, labor-related incomes declined. Since the CHE represents the more severe status of chronic diseases, so it can be interpreted that CHE affects the work power of household members negatively. This interpretation is supported by the fact that nonlabor-related incomes were not affected. Of all income types, the only increase occurred in private transfer income. It can be considered as borrowing money from nearby acquaintances to offset OOP and reduced earned income. In other words, Korean people are heavily relying on social networks than the social security system which must protect household finances by giving public transfer income. However, the private transfer income may not be enough to cover the decreasing disposable income. In addition, even if a household reduces the expenditure of non-medical expenses, the total living expenses remain elevated because of OOP. As the living expenses increase and income decreases, the household cash flow shows a deficit.

Existing studies argued that exploiting liability, borrowing, and use savings are the financial coping strategy that can protect households from poverty [5, 6]; however, this strategy breaks the balance of financial fitness in households. In this study, we demonstrated that several financial strain indicators deteriorated. These are important facts for an economically advanced country like Korea because one of the reasons for bankruptcy in households in the Korean community is that the households fail to balance the liability/assets ratio. There was no significant increase in liability in this study; however, the relative size of assets could be more critical than absolute liability size. Even a small liability, if a household is incapable of servicing it, will cause an over-liability situation [7]. If assets are reduced, the ability to maintain liability falls. Households can be classified as credit-impaired in the event of a default and may become bankrupt [22]. The financial ratio analysis was conducted to understand this point.

The limitations of this study are as follows: this study did not analyze whether CHE causally affects financial indicators. This is about the correlation. In order to analyze the causal impact, it is necessary to measure the amount of difference in financial indicators before and after the time of the occurrence of CHE. However, it is difficult to calculate the difference because the financial indicators are measured as a ratio. And there is a problem that selection bias may occur as the number of samples decreases during the calculation process. In addition, there is a possibility that the relationship between the CHE indicator and the Surplus indicator has endogeneity. For example, households with a strong consumption propensity will show high in both indicators, and households with low consumption propensity will show low.

Also, this study is the use of family units of independent and dependent variables. Due to this, we could not use individual units of control variables, such as self-reported health. We suggest that subsequent studies should utilize panel analysis, considering that 
chronic diseases are suffered over the long term. In particular, liability may have a positive impact on maintaining consumption in households in the short term, but it would likely become an economic burden to repay over the long term. In other words, since the economic burden of liability occurs over time, we must observe a long-term impact. Moreover, income, assets, and liabilities are influenced by the characteristics of households that are not observed; however, panel analysis can control for such effects.

\section{Abbreviations}

CHE: Catastrophic Health Expenditure; OOP: Out-Of-Pocket; KoWePS: Korea Welfare Panel Study; LADR: Ladder Capital Corp; VIF: Variance Inflation Factor; OR: Odds Ratio

\section{Declarations}

Ethics approval and consent to participate: Approval of IRB exemption for this study was granted by the Korea University Institutional Review Board (approval number: KUIRB-2019-0214-01), given the study's retrospective nature(https://www.koweps.re.kr:442/main.do).

Consent for publication: There is consent for publication.

\section{Availability of data and materials}

We used publicly available and reliable secondary data from KoWePS, which was provided through the de-identified samples. The investigator of KoWePS visited the participants' households, met the respondent, and received informed consent. We received ethical right of our research participants.

\section{Competing interests}

There is no conflict of interest

\section{Funding}

This study was supported by the Korea Medical Device Development Fund grant, funded by the Korean government (the Ministry of Science and ICT, the Ministry of Trade, Industry and Energy, the Ministry of Health \& Welfare, Republic of Korea, the Ministry of Food and Drug Safety), (Project Number: KMDF_PR_20200901_0185, 9991007416).

\section{Authors' contributions}

$\mathrm{HJ}$ were involved in data analyzing and interpreting of this study, YDK and JWN were contributed to drafting and writing manuscript. These all author read and approved final manuscript

\section{Acknowledgements}

Not applicable

\section{Author information}

${ }^{1}$ Post Doc, Department of Health Administration, Graduate School-BK21 Graduate program of developing glocal experts in health policy and management, Yonsei University, Wonju, South Korea

${ }^{2}$ Department of Humanities and Social Medicine, College of Medicine and Catholic Institute for Healthcare Management, The Catholic University of Korea, Seoul, Korea

${ }^{3}$ Devision of Health Administration, College of Software and Digital Healthcare Convergence, Yonsei University, Wonju, Korea

\section{References}


1. Wagstaff A, Flores G, Hsu J, Smitz M-F, Chepynoga K, Buisman LR, et al. Progress on catastrophic health spending in 133 countries: a retrospective observational study. The Lancet Global Health. 2018;6(2):e169-e79.

2. Wagstaff A, Lindelow M. Can insurance increase financial risk?: The curious case of health insurance in China. Journal of health economics. 2008;27(4):990-1005.

3. Choi J-W, Choi J-W, Kim J-H, Yoo K-B, Park E-C. Association between chronic disease and catastrophic health expenditure in Korea. BMC health services research. 2015;15(1):1-8.

4. Kankeu HT, Saksena P, Xu K, Evans DB. The financial burden from non-communicable diseases in low-and middle-income countries: a literature review. Health Research Policy and Systems. 2013;11(1):1-12.

5. Flores G, Krishnakumar J, O'Donnell O, Van Doorslaer E. Coping with health-care costs: implications for the measurement of catastrophic expenditures and poverty. Health economics. 2008;17(12):1393-412.

6. Babiarz P, Widdows R, Yilmazer T. Borrowing to cope with adverse health events: Liquidity constraints, insurance coverage, and unsecured debt. Health economics. 2013;22(10):1177-98.

7. Keese M, Schmitz H. Broke, ill, and obese: Is there an effect of household debt on health? Review of Income and Wealth. 2014;60(3):525-41.

8. Batabyal S. Temporal causality and the dynamics of crime and delinquency. Atlantic Economic Journal. 2011;39(4):421-41.

9. Svynarenko R, Zhang Q, Kim H. The financial burden of Cancer: financial ratio analysis. Journal of Family and Economic Issues. 2019;40(2):165-79.

10. Prather CG. The ratio analysis technique applied to personal financial statements: Development of household norms. Financial Counseling and Planning. 1990;1:53-69.

11. DeVaney SA. Change in household financial ratios between 1983 and 1986: Were American households improving their financial status. Financial Counseling and Planning. 1993;4(3):I-46.

12. Wagstaff A, Doorslaer Ev. Catastrophe and impoverishment in paying for health care: with applications to Vietnam 1993-1998. Health economics. 2003;12(11):921-33.

13. Mondal S, Kanjilal B, Peters DH, Lucas H. Catastrophic out-of-pocket payment for health care and its impact on households: Experience from West Bengal, India. Future Health Systems, Innovations for equity. 2010.

14. Yang S, Jung J. A study on household financial indexes of Korea FP (Financial Planner). Financial Planning Review, 3 (1). 2010:109-37.

15. Yang S, Joo S, Cha K, Kim M. A study of financial ratios guidelines for Korean households. Financial Planning Review. 2013;6(3):143-81.

16. jung Park M, DeVaney SA. Examining a model of economic well-being based on financial ratios. Consumer Interests Annual. 2007;53.

17. Lytton RH, Garman ET, Porter N. How to use financial ratios when advising clients. Journal of Financial Counseling and Planning. 1991;2(1).

18. Griffith R, editor Personal financial statement analysis: A modest beginning. Proceedings, Third Annual Conference of the Association of Financial Counseling and Planning Education; 1985: AFCPE Ames, IA.

19. Baek E. The Effects of the Retirement on Households' Financial Soundness. Financial Planning Review. 2017;10(3).

20. Harness NJ, Chatterjee S, Finke M. HOUSEHOLD FINANCIAL RATIOS: A REVIEW OF LITERATURE. Journal of Personal Finance. 2008;6(4).

21. Lytton, Grable JE, Klock DD. The process of financial planning: Developing a financial plan: National Underwriter Company; 2012.

22. Connell S. Building a creative economy in South Korea: Analyzing the plans and possibilities for new economic growth. 2014: On Korea. 2014;7.

\section{Supplementary Files}

This is a list of supplementary files associated with this preprint. Click to download. 
- 2.FinancialburdenofCHEanalysisd1.xls

- Supplementarytable1.docx

- Supplementarytable2.docx

- Supplementarytable3.docx

- Supplementarytable4.docx

- Supplementarytable5.docx

- Supplementarytable6.docx

- Supplementarytable7.docx

- Supplementarytable8.docx

- Supplementarytable9.docx

- Supplementarytable10.docx

- Supplementarytable11.docx

- Supplementarytable12.docx

- Supplementarytable13.docx

- Supplementarytable14.docx

- Supplementarytable15.docx

- Supplementarytable16.docx

- Supplementarytable17.docx 